\title{
Effects of Propofol on Several Membrane Characteristics of Cervical Cancer Cell Lines
}

\author{
Fan Zhang ${ }^{a}$ Changsong Wanga,e Yinghua Cuia Shuping Li ${ }^{b}$ Yuanfei Yaoc,f \\ Yanpeng $\mathrm{Ci}^{\mathrm{c}}$ Jinghe Wang ${ }^{\mathrm{d}}$ Wei Hou ${ }^{\mathrm{a}}$ Anqi Wu${ }^{\mathrm{a}}$ Enyou $\mathrm{Li}^{\mathrm{a}}$
}

aDepartment of Anesthesiology, First Affiliated Hospital of Harbin Medical University, ${ }^{b} S c h o o l ~ o f$ Mechatronics Engineering, Harbin Institute of Technology, 'School of Life Science and Technology, Harbin Institute of Technology, ${ }^{\mathrm{d} C e n t e r}$ for Precision Engineering, Harbin Institute of Technology, Harbin, eDepartment of critical care medicine, the Third Affiliated Hospital of Harbin Medical University, Harbin, The Third Affiliated Hospital of Harbin Medical University, Harbin, China

\section{Key words}

HeLa cell $\cdot$ Propofol $\cdot$ AFM $\cdot$ Cytoskeleton $\cdot$ Migration

\begin{abstract}
Background: Although significant advances have been made toward understanding the molecular mechanisms underlying the effect of propofol on tumor cell metastasis, less is known regarding how cell membrane and cytoskeletal ultrastructure are affected in this process. Here, we investigated the relationship between cell morphology and cell size, which are features mainly defined by the cytoskeleton. Methods: To confirm the effects of propofol on the migratory ability of human cervical carcinoma cells, cell migration and invasion were examined through scratch wound healing and transwell membrane assays. Furthermore, HeLa cells cultivated with different concentrations of propofol were examined by confocal microscopy and atomic force microscopy (AFM), and the mean optical density and migration ability of these cells were also assessed. In addition, cell membrane morphology was inspected using AFM. Results: The results of the wound healing and transwell membrane assays indicated that propofol decreases the migratory ability of cervical carcinoma cells compared to control cells. A comparative analysis of the test results revealed that short-term $(3 \mathrm{~h})$ exposure to propofol induced marked changes in cell membrane microstructure and in the cytoskeleton in a dosedependent manner. These morphological changes in the cell membrane were accompanied by cytoskeleton (F-actin) derangement. The present findings demonstrate a close relationship between changes in cell membrane ultrastructure and cytoskeletal alterations (F-actin) in propofol-treated HeLa cells. AFM scanning analysis showed that cell membrane ultrastructure was significantly changed, including a clear reduction in membrane roughness. Conclusion: The influence of propofol on the HeLa cell cytoskeleton can be directly reflected by changes in cellular morphology, as assessed by AFM. Moreover, the use of AFM is a good method for investigating propofol-mediated changes within cytoskeletal ultrastructure.




\section{Cellular Physiology Cell Physiol Biochem 2016;40:172-182

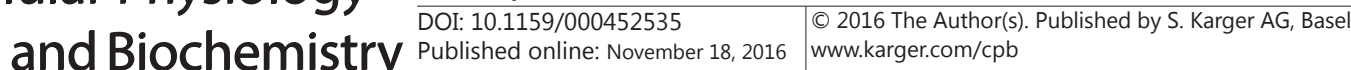 \\ Zhang et al.: Effects of Propofol on Membrane Characteristics}

\section{Introduction}

Surgery is currently the first-line treatment for solid tumors [1]. A variety of therapies, including combinations of surgery, chemotherapy and radiation, are used to prevent resistance and relapse and thereby prolong survival time, but the patients administered these therapies still have a poor prognosis. Metastatic recurrence is a major cause of cancerrelated death, and tumor cell migration is the initial step in the metastatic process [2-4]. Recent studies have focused on dissecting the role and prognostic value of anesthetic drugs in the suppression of cell migration and invasion for multiple tumor types. Previous studies have indicated that propofol (2, 6-diisopropylphenol), one of the most extensively used intravenous anesthetic agents during cancer resection surgery, influences the biological behavior of cancer cells, including their proliferation, motility, and invasiveness [5-8]. Retrospective clinical data and results generated using animal models suggest that the administration of certain anesthetic drugs and techniques after surgery for cancer attenuate immunosuppression and minimize metastasis [9-17].

The cytoskeleton primarily governs cell morphology and size, which are closely related to tumor progression and metastasis [18-25]. The accumulated body of evidence indicates that propofol inhibits the formation of actin stress fibers and focal adhesions as well as actin cytoskeleton reorganization $[14,26]$. However, the manner in which changes in cell membrane ultrastructure are associated with this process remains unclear.

The cell membrane plays important roles in cellular physiological processes, including by regulating a variety of cell functions, such as cellular transport, signal transduction, cellsurface recognition, cell survival, energy conversion, and cell differentiation. In addition, the cell membrane also constitutes a barrier between the external and internal cellular environment and plays a key role as an exchange interface between these environments. Therefore, changes in cell membrane structure directly reflect the actual state of a cell [27, 28].

Tumor cell lines have been studied using various microscopic techniques, such as fluorescence microscopy, confocal microscopy, transmission electron microscopy (TEM) and scanning electron microscopy (SEM). These methods provide the best resolution, but some of these techniques, such as TEM and SEM, require complex sample-preparation processes, which include fixation and drying procedures [27-32]. A large quantity of crucial biological information is inevitably lost during these processes. Therefore, progress in new microscopic technologies has significantly advanced research on tumor biology. For example, atomic force microscopy (AFM), which provides nanometer resolution, is frequently used for imaging biological samples in molecular and cellular biology studies [33, 34]. Notably, this technique records the surface topography of biological samples under physiological conditions without requiring complicated sample preparation [35-37]. Therefore, AFM is a good method for investigating the ultrastructural changes on the membrane surface that accompany propofol-induced changes in the cytoskeleton.

The present study used AFM-based analysis of morphological changes in cell membrane ultrastructure as well as cytoskeletal alterations in human cervical carcinoma (HeLa) cells.

\section{Materials and Methods}

Materials and instruments

We purchased human cervical cancer cell lines from the American Type Culture Collection. Propofol was obtained from Sigma-Aldrich (USA). FITC-labeled phalloidin and DAPI (4', 6-diamidino-2-phenylindole) were procured from Sigma (USA) and AppliChem (Darmstadt, Germany), respectively. An antibody against actin was purchased from Santa Cruz Biotechnology. All solvents and other chemicals were obtained from local commercial suppliers. All of these materials were of analytical reagent grade unless otherwise stated. Measurements were performed using an Agilent Technologies 5500 Scanning Probe Microscope, a Zeiss Axiovert 200M inverted microscope and a Zeiss LSM 510 META confocal microscope. 


\section{Cellular Physiology Cell Physiol Biochem 2016;40:172-182 \begin{tabular}{l|l|l} 
and Biochemistry $\begin{array}{l}\text { DOI: 10.1159/000452535 } \\
\text { Published online: November 18, } 2016\end{array}$ & $\begin{array}{l}\text { (c) } 2016 \text { The Author(s). Published by S. Karger AG, Basel } \\
\text { www.karger.com/cpb }\end{array}$
\end{tabular} \\ Zhang et al.: Effects of Propofol on Membrane Characteristics}

Cell culture

Cells were maintained as adherent monolayer cultures in high-glucose Dulbecco's Modified Eagle's Medium (DMEM, Gibco, USA) containing $10 \%$ fetal bovine serum (FBS, Gibco, USA) and incubated at $37^{\circ} \mathrm{C}$ with $5 \% \mathrm{CO}_{2}$. We replaced the medium every three days, and once the cells reached $80-85 \%$ confluence, we washed the cells twice with PBS and then submitted them to digestion with $0.02 \%$ EDTA (Sigma, USA) and $0.25 \%$ trypsin (Sigma-Aldrich, USA).

\section{Drug treatments}

Cells were seeded in 24-well plates and 35-mm Petri dishes at a density of $2 \times 10^{5}$ cells $/ \mathrm{ml}$ per well and incubated in a humidified incubator with $5 \% \mathrm{CO}_{2}$ at $37^{\circ} \mathrm{C}$. After $24 \mathrm{~h}$, the culture medium was replaced with culture medium supplemented with a specific concentration $(20 \mu \mathrm{M}, 30 \mu \mathrm{M}$ or $40 \mu \mathrm{M})$ of propofol, and the cells were then returned to culture. We employed a 3-h propofol treatment time. The treatment time and doses were based on those commonly used in clinical applications and in vitro cell research. Control treatments with corresponding concentrations of dimethylsulfoxide (DMSO) were performed in parallel.

\section{Cell proliferation assay}

Cell proliferation was analyzed by MTT assay and CFSE. Briefly, $3 \times 10^{3}$ cells were plated in $100 \mu \mathrm{l}$ of medium per well in 96-well dishes, and at the indicated time points, the medium was removed and replaced with $100 \mu \mathrm{l}$ of fresh culture medium containing $1.2 \mathrm{mM}$ MTT or $2.5 \mu \mathrm{M}$ CFSE. For the MTT assay, the reaction was incubated at $37^{\circ} \mathrm{C}$ for $4 \mathrm{~h}$, and $100 \mu \mathrm{l}$ of SDS- $\mathrm{HCl}$ solution $(10 \%$ SDS and $0.01 \mathrm{M} \mathrm{HCl})$ was then added to each well. After incubation at $37^{\circ} \mathrm{C}$ for $4 \mathrm{~h}$, each sample was mixed using a pipette, and the absorbance at $570 \mathrm{~nm}$ was read. In the CFSE assay, the fluorescence of the enzyme-labeled cells was quantified (CFSE, Irvine Scientific, USA).

\section{Scratch wound healing assay}

For cell migration assays, we seeded cells into 24-well plates at a density of $0.5 \times 10^{4} / \mathrm{cm}^{2}$ and allowed them to grow into confluent monolayers. The cells were then treated with propofol, and a 3-mm scratch wound was made across the diameter of each plate using a sterile $20-\mu \mathrm{l}$ pipette tip. Phase-contrast microscopy was used to observe the wounds, and photographs were taken both immediately and $12 \mathrm{~h}$ after wounding. The images were analyzed using ImageJ software. For each independent experiment, we compared the wound width with the initial width in different fields. Cell migration rate was calculated as (1-A12/A0) \%, where $\mathrm{A} 0$ and $\mathrm{A} 12$ represent the scratch distances at 0 and 12 hours, respectively.

\section{Transwell migration assay}

Transwell migration assays were performed using a Millicell culture plate with an 8.0 - $\mu \mathrm{m}$ PET insert (Millipore Corporation, USA). First, $5 \times 10^{4}$ cells in $200 \mathrm{ml}$ of serum-free medium were plated per upper chamber. The chambers were placed into 24-well plates, and $500 \mu \mathrm{l}$ of DMEM supplemented with $10 \%$ fetal calf serum was added per well. After incubation for $12 \mathrm{~h}$ at $37^{\circ} \mathrm{C}$, the cells that had traversed the membrane were fixed and visualized by crystal violet staining. Cells in three random fields per chamber were counted using a phase contrast microscope.

\section{Immunofluorescent staining}

HeLa cells were cultured on coverslips in DMEM containing 10\% fetal bovine serum for $24 \mathrm{~h}$ (reaching approximately 60\% confluence). The cells were then treated with propofol for $3 \mathrm{~h}$, fixed in $4 \%$ paraformaldehyde in PBS buffer ( $\mathrm{pH} 7.4$ ) for $10 \mathrm{~min}$ at room temperature and permeabilized in PBS supplemented with $1 \%$ Triton X-100 for $10 \mathrm{~min}$ at room temperature. The cells were subsequently washed three times with cold PBS and then blocked in PBS supplemented with 2.5\% bovine serum albumin (BSA) for $1 \mathrm{~h}$ at room temperature. Actin filaments were stained with fluorescently labeled phalloidin for $1 \mathrm{~h}$ at $37^{\circ} \mathrm{C}$. The cells were then rinsed three times with PBST and once with PBS. The cells were then incubated in DAPI for 2 min for the identification of DNA. A Zeiss LSM 510 META confocal microscope with a 40× oil immersion objective (NA, 1.4) was used to mount and visualize the coverslips. Figure 4 shows a typical image from each group.

\section{KARGER}




\section{Cellular Physiology Cell Physiol Biochem 2016;40:172-182 \begin{tabular}{l|l|l} 
and Biochemistry & $\begin{array}{l}\text { DOI: 10.1159/000452535 } \\
\text { Published online: November 18, } 2016\end{array}$ & $\begin{array}{l}\text { (c) } 2016 \text { The Author(s). Published by S. Karger AG, Basel } \\
\text { www.karger.com/cpb }\end{array}$
\end{tabular} \\ Zhang et al.: Effects of Propofol on Membrane Characteristics}

\section{Antibodies and western blotting}

The following primary antibodies were used: mouse anti-Caspase-3 (Invitrogen, USA), mouse antiGAPDH (KANGCHEN, China), mouse anti-PARP (Sigma, USA), and mouse anti-F-actin (Santa Cruz, USA). For antibody staining, cells were washed twice with ice-cold PBS and lysed in RIPA lysis buffer (50 mM Tris-HCl, pH 7.4, $150 \mathrm{mM} \mathrm{NaCl}, 1 \% \mathrm{NP}-40,0.1 \% \mathrm{SDS}$, and $0.5 \%$ sodium deoxycholate) containing $10 \mu \mathrm{g} /$ $\mathrm{ml}$ aprotinin, $10 \mu \mathrm{g} / \mathrm{ml}$ leupeptin and $1 \mathrm{mM}$ PMSF. Whole-cell lysates were centrifuged at 20,000 $\times \mathrm{g}$ and $4^{\circ} \mathrm{C}$ for $10 \mathrm{~min}$, and equal amounts of the cell lysates were electrophoresed on $12 \%$ SDS-polyacrylamide amide gels. Proteins were then transferred to a nitrocellulose membrane, and the membranes were blocked with $5 \%$ defatted milk, probed with the indicated primary antibodies overnight at $4{ }^{\circ} \mathrm{C}$ and incubated with secondary antibodies conjugated to horseradish peroxidase (Sigma, USA) for $1 \mathrm{~h}$ at RT. An ECL western blotting analysis system (Amersham Biosciences, USA) was used to detect the substrates.

\section{Measurement of the mean optical density}

For each cell measurement, the mean optical density (MOD) of F-actin was determined using immunofluorescence images. ImageJ (v. 1.42 q) software, which was created by the National Institutes of Health (NIH), was used to measure the areas and integrated optical densities. The MOD was calculated using the following equation (Eq): MOD = integrated density / cell area.

\section{AFM imaging}

HeLa cells were cultured in 35-mm Petri dishes and placed on a 325 Temperature Controller (LakeShore, USA), which ensured a constant temperature of $37^{\circ} \mathrm{C}$ throughout the AFM nanoindentation assay. AFM deflection images of HeLa cell surfaces were acquired in an atmospheric environment using the contact mode. Image acquisition was performed with PicoView 1.10 software. An Agilent Technologies 5500 Scanning Probe Microscope and AFM probe tips (Type: OMCL-TR800PSA-W, Olympus, Japan) were used for cell scanning. We then obtained detailed cantilever information based on the cantilever manufacturer's specifications. The tip spring constant was $0.15 \mathrm{~N} / \mathrm{m}$; the resonance frequency was $24 \mathrm{kHz}$; the deflection sensitivity was $15 \mathrm{~nm} / \mathrm{V}$; and the force constant was $0.2 \mathrm{~N} / \mathrm{m}$. All images were acquired using a $256 \times 256$ data-point resolution and a scan delay of $10 \mathrm{~ms}$. Young's modulus (tensile modulus) measurements were taken in the force/volume mode at a rate of $1 \mathrm{~Hz}$, and the forward/reverse velocity was $3 \mu \mathrm{m} / \mathrm{sec}$. In this study, we performed at least five independent cell-imaging scans for each group.

\section{Statistical analysis}

Statistical analyses were performed using the Kruskal-Wallis H-test and one-way ANOVA when appropriate. Data obtained from three independent experiments are presented as the means \pm S.D. The results were processed using SAS version 9.1, and P values less than 0.05 were considered statistically significant.

\section{Results}

Propofol affects cell morphology and inhibits cervical carcinoma cell proliferation

To investigate the in vitro effect of propofol on cell morphology, we detected changes in the general morphology of cancer cells treated with propofol. HeLa cells were exposed to different propofol concentrations for different time periods. The obtained images revealed that all living cells were highly refractive and presented a distinct and clear shape under visible light (Fig. 1a). Therefore, treatment with the three concentrations of propofol for $3 \mathrm{~h}$ did not induce any significant damage to cellular integrity.

To determine whether propofol exerts an inhibitory effect on HeLa cell proliferation, we measured cell growth using MTT assays. Cells were treated with increasing concentrations (20 to $40 \mu \mathrm{M}$ ) of propofol for $24 \mathrm{~h}$ or $48 \mathrm{~h}$, and cell proliferation was analyzed. The results indicate that propofol decreased HeLa cell proliferation in a dose-dependent manner (Fig. 1b). A live cell-staining assay revealed a significant decrease in the number of cells after treatment with $40 \mu \mathrm{M}$ propofol compared with control cells (Fig. 1c). These results indicate that propofol inhibits cervical carcinoma cell proliferation. 


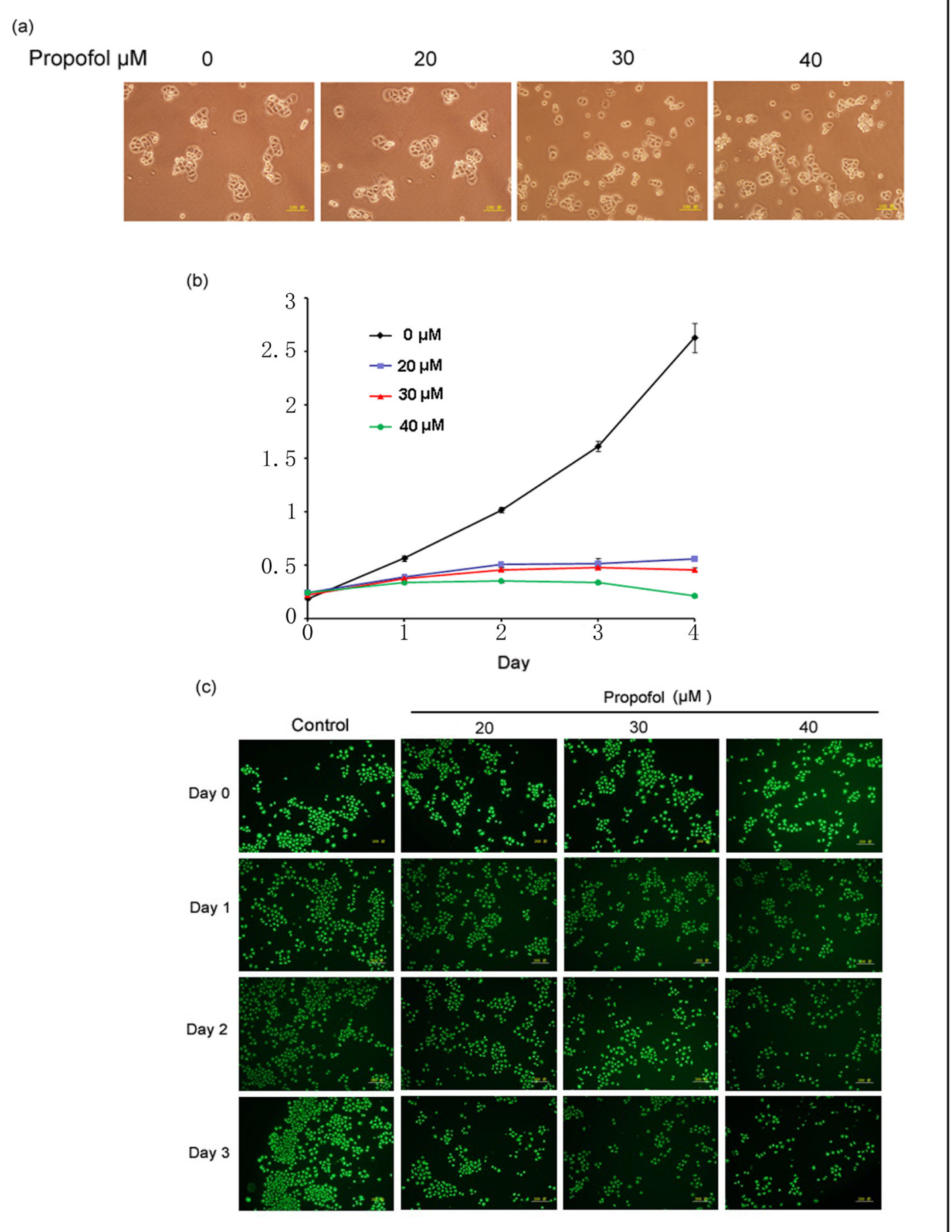

Fig. 1. Propofol affects cell morphology and inhibits cervical carcinoma cell proliferation. (a) Morphology of HeLa cells treated with different concentrations of propofol. (b, c) Cell proliferation at days 0, 1, 2, 3, and 4 was measured through MTT and CFSE assays.

\section{Propofol decreased cell migration in vitro}

To study the effect of propofol on cell migration, the role of propofol in cervical cancer cell metastasis ( $\mathrm{SiHa}$ and HeLa) was examined through a scratch wound healing assay. As shown in Figure $2 \mathrm{a}$ and $2 \mathrm{~b}$, control cells migrated significantly faster than propofoltreated cells. We also found that the migration ability of HeLa cells was almost completely 


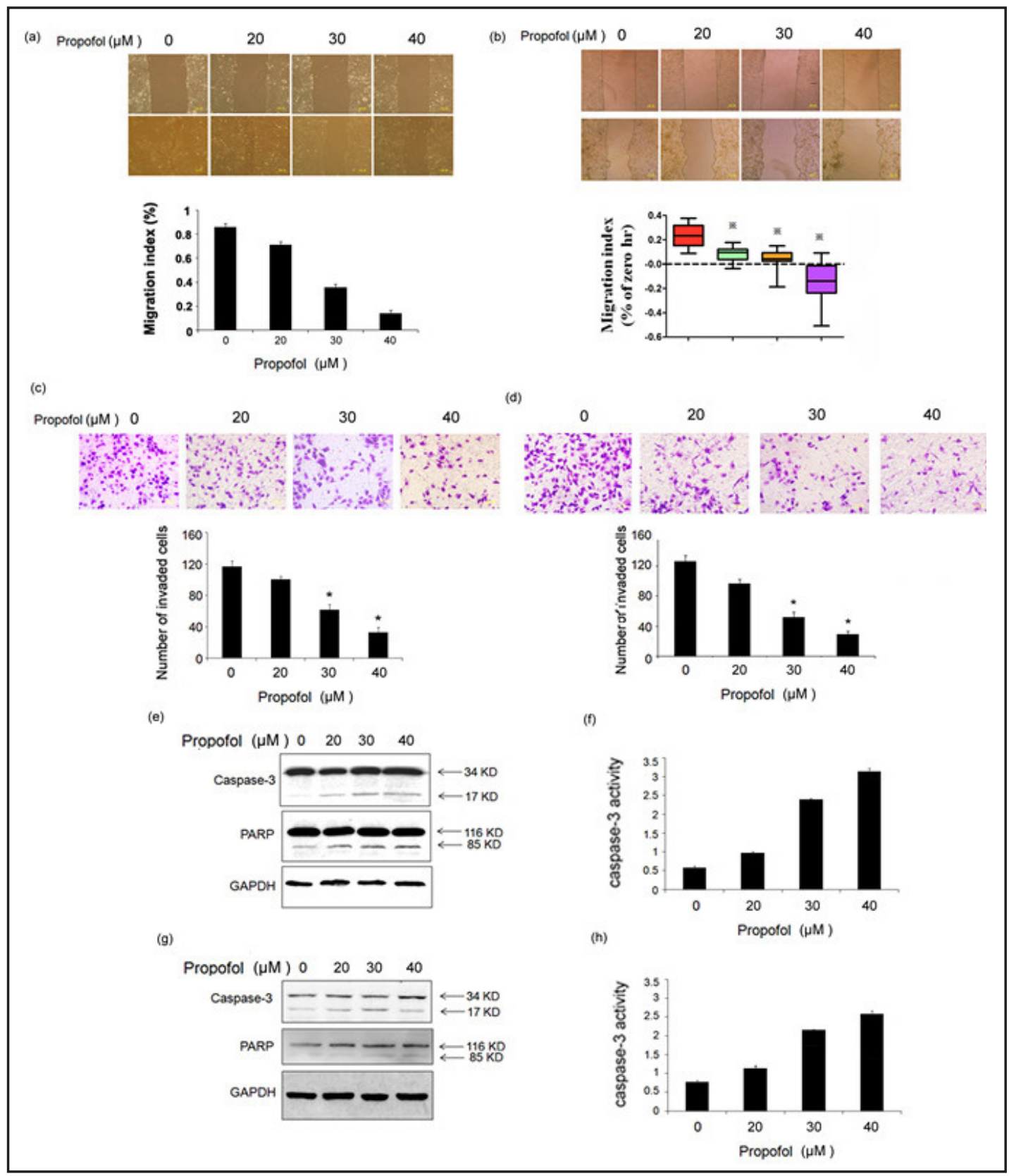

Fig. 2. Propofol decreases cell migration in vitro. $(\mathrm{a}, \mathrm{b})$ Alterations in SiHa and HeLa cell migration following treatment with propofol were assessed using a wound scratch healing assay and light microscopy (40x). (c, d) Alterations in SiHa and HeLa cell motility following treatment with propofol were assessed using a Transwell migration assay. Cells that traversed the membrane were visualized by crystal violet staining. The results are the average of three independent experiments $(p<0.05)$. (e) Expression levels of Caspase-3 and PARP in HeLa cells were detected by western blotting, using GAPDH as a control. (f) Caspase-3 activity in HeLa cells treated with different concentrations of propofol. (g) Expression of Caspase-3 and PARP in SiHa cells. (h) Caspase-3 activity in SiHa cells treated with different concentrations of propofol.

blocked by treatment with $30 \mu \mathrm{M}$ propofol. Notably, propofol treatment for $12 \mathrm{~h}$ decreased cell migration in a concentration-dependent manner. These results suggest that propofol decreases cervical cancer cell migration in vitro and that the reduced migration potential may be partially associated with cytoskeletal depolymerization or derangement. 


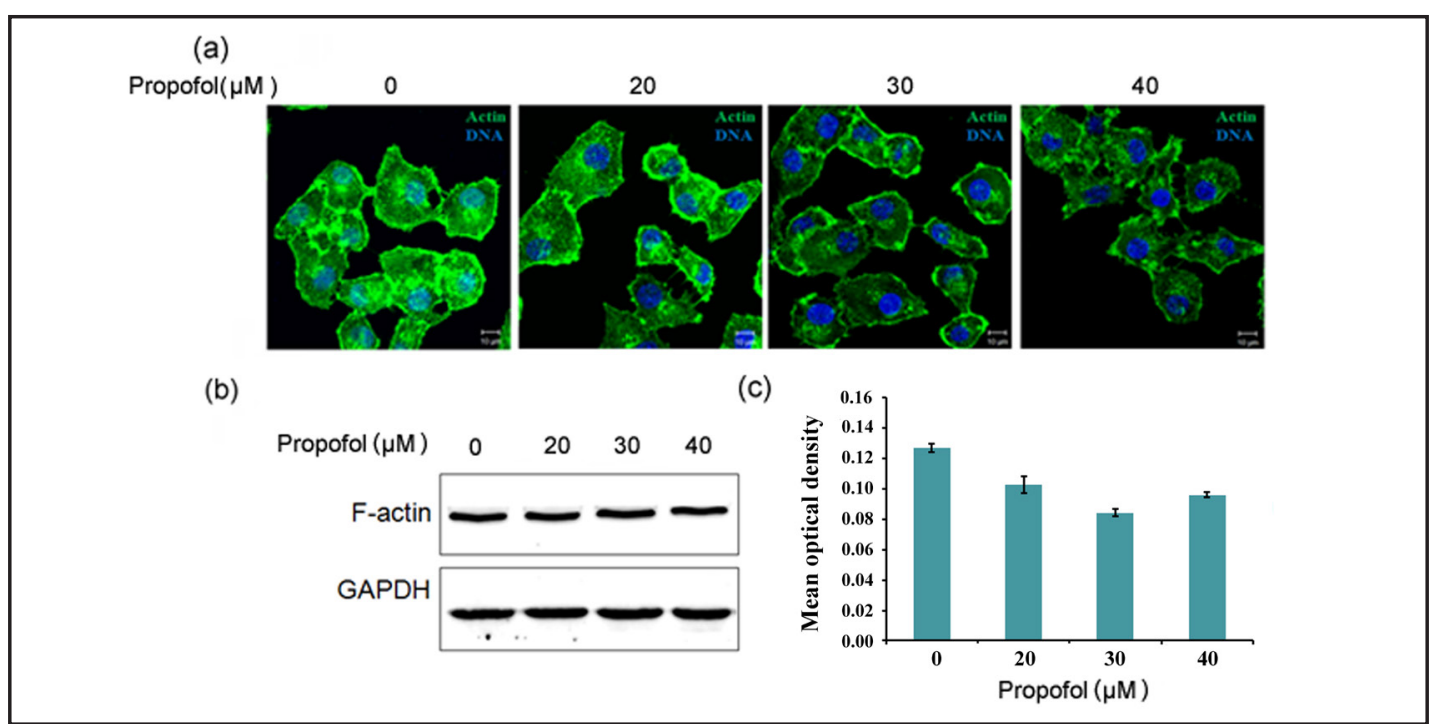

Fig. 3. Propofol regulates cytoskeletal structural stability. (a) Microfilaments were stained with fluorescein isothiocyanate (FITC)-conjugated phalloidin. DNA was counterstained with DAPI. Bar, $10 \mu \mathrm{m}$. (b) F-actin expression was detected by western blotting. (c) The data are presented as the means \pm SD. ${ }^{*} p<0.05$ compared with control cells, as determined through one-way ANOVA.

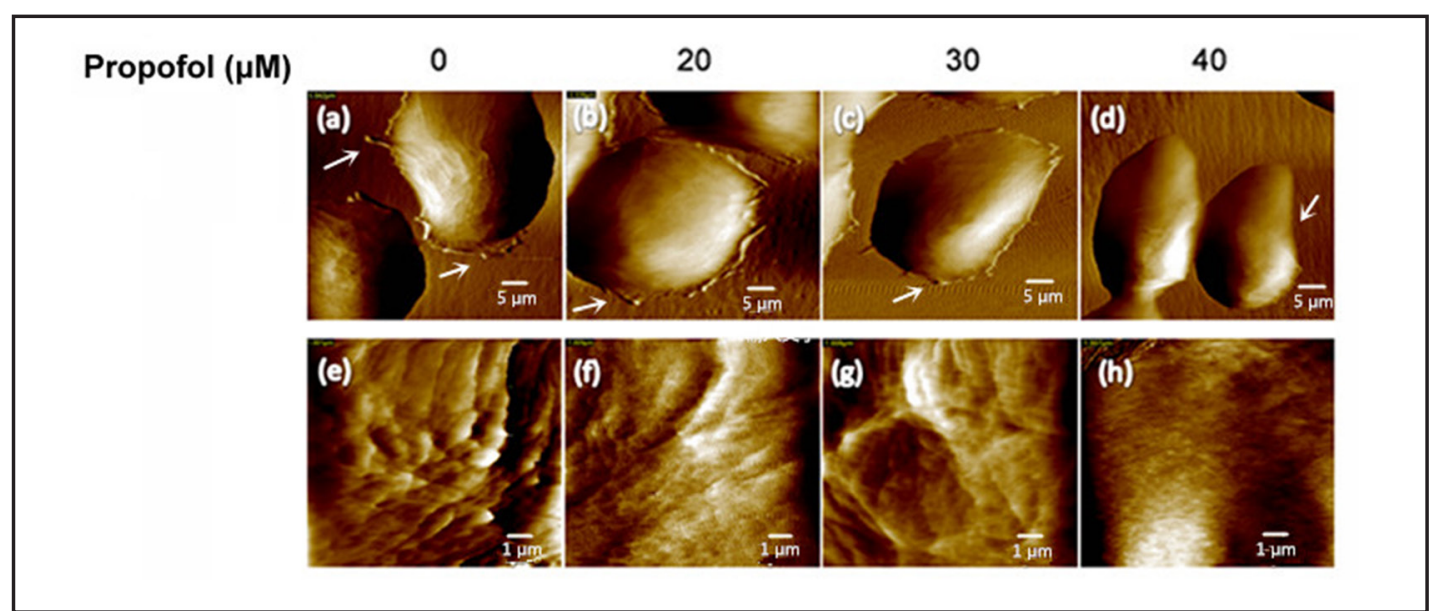

Fig. 4. Propofol affects membrane ultrastructure in HeLa cells. (a, b, c, d) AFM images of HeLa cells. Cellular pseudopodia at the edges of HeLa cells gradually retracted after propofol treatment. (e, f, g, h) Cellular membrane ultrastructure. Membrane surface roughness decreased after treatment with propofol, and the cell membrane became smooth.

Recently published data suggest that propofol inhibits the invasion of cancer cells. In the present study, transwell migration assay results revealed that treatment with $40 \mu \mathrm{M}$ propofol reduced the number of cells $(41 \pm 6$ cells) that permeated the transwell membrane compared to the control cells. Furthermore, treatment with $30 \mu \mathrm{M}$ propofol also significantly suppressed the number of migrated cells compared to the control cells (Fig. 2c and 2d). These results indicate that propofol inhibits the migration of cervical cancer cells.

We then determined whether propofol-mediated decreases in cervical cancer cell viability and migration result from the induction of apoptosis. Analysis of apoptosis marker expression in propofol-treated HeLa cells by western blotting revealed that propofol dose- and time-dependently increased the levels of the apoptosis markers Caspase- 3 and PARP (Figs. $2 \mathrm{e}$ and $2 \mathrm{f}$ ). Collectively, our results indicate that propofol effectively promotes apoptosis in HeLa cells; similar results were obtained with the SiHa cell line (Figs. 2g and 2h). 


\section{Cellular Physiology Cell Physiol Biochem 2016;40:172-182 \begin{tabular}{l|l} 
and Biochemistry Published online: November 18, 2016 & $\begin{array}{l}\text { (c) } 2016 \text { The Author(s). Published by S. Karger AG, Basel } \\
\text { www.karger.com/cpb }\end{array}$
\end{tabular} \\ Zhang et al.: Effects of Propofol on Membrane Characteristics}

\section{Propofol regulates cytoskeletal structural stability}

To further investigate the biological effect of propofol on the organization of the actin cytoskeleton, we visualized F-actin organization in HeLa cells through immunofluorescence staining. As shown in Figure 3a, F-actin organization in the cytoskeletons of the control cells exhibited a dense and linear isotropic network throughout the cell body. However, F-actin structure in the cytoskeletons of the cells treated with propofol showed a state of depolymerization, and the fluorescence intensity was significantly attenuated. We then assessed the impact of a higher propofol concentration $(40 \mu \mathrm{M})$ on F-actin organization and found that the F-actin filaments in the treated cells were sparsely distributed, diffusely spread throughout the cytoplasm and appeared as discontinuous, short, and linearly distributed points. In addition, the cytoplasms and nuclei of these cells exhibited markedly reduced fluorescence intensity. Immunofluorescence microscopy analyses demonstrated that the amounts of F-actin in the cytoplasm and nucleus were significantly reduced.

To study the degree of actin polymerization, we measured the expression levels of F-actin using western blot analysis (Fig. 3b) and found that F-actin expression did not significantly differ among the different groups of cells. Previous studies have demonstrated that a lower MOD is related to a decreased intensity and a reduced organization of F-actin. Therefore, we examined the MOD in the different cell groups. Notably, the propofol-treated cells exhibited a significantly lower MOD than the control cells (Fig. 3c). These results suggest that propofol disrupts the cellular cytoskeleton.

\section{Propofol affects the membrane ultrastructure of HeLa cells}

The migratory and aggressive properties of cancer cells can be evaluated by assessing cellsurface morphology using AFM. We observed a variety of changes in cellular ultrastructure and surface morphology in the propofol-treated cells. The edges of these cells gradually retracted after propofol treatment, and their membrane surface roughness decreased after treatment in a dose-dependent manner. As shown in Figures $4 \mathrm{a}$ and $4 \mathrm{e}$, the cells in the control group presented a regular shape with well-spread cellular edges, and the membrane surfaces of these cells were scaly in appearance. Minor changes, including decreases in membrane surface roughness, were noted following treatment with $20 \mu \mathrm{M}$ propofol. In addition, treatment with $30 \mu \mathrm{M}$ propofol resulted in marked retraction of pseudopodia at the edges of HeLa cells (Figs. 4c and 4g). Further observations revealed that the membrane surface roughness of these cells also decreased significantly. The pseudopodia at the edges of the cells treated with $40 \mu \mathrm{M}$ propofol disappeared after $3 \mathrm{~h}$ of treatment (Figs. $4 \mathrm{~d}$ and $4 \mathrm{~h}$ ). Fine structural analyses revealed further decreases in cellular roughness and that the cell membrane became smooth. These results suggest that propofol reduces the migration of cervical cancer cells by changing cellular surface ultrastructure.

\section{Discussion}

It is well accepted that cell structure determines cell function, and the cytoskeleton is the structural framework that predominantly shapes a cell [19]. Cytoskeletal reorganization is a critical step in the process of tumor cell metastasis, which leads to the spread of cancer and to treatment failure $[22,23,38]$. Propofol has been found to influence the biological activity of several tumor cell lines by inducing cytoskeletal reorganization [26], but the processes driving the corresponding alterations in membrane ultrastructure have not been determined. Here, we used high-resolution AFM to investigate propofol-induced changes in membrane surface ultrastructure. The present study showed that alterations in the cell cytoskeleton (F-actin) were accompanied by changes in cell migration ability and in membrane surface ultrastructure. Three hours of propofol stimulation caused F-actin in the cytoskeleton to depolymerize and eliminated the fluorescence intensity of F-actin. As a result, there was less F-actin organization below the plasma membrane, which was observed as a reduced MOD in immunofluorescence images. We also evaluated how propofol affects F-actin 


\section{Cellular Physiology Cell Physiol Biochem 2016;40:172-182

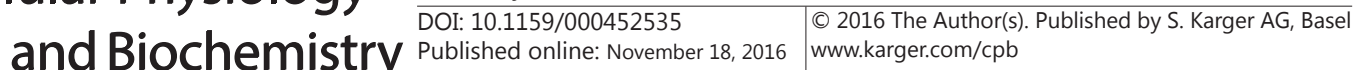 \\ Zhang et al.: Effects of Propofol on Membrane Characteristics}

protein expression using an IB assay. The results showed that propofol treatment induced no obvious changes in F-actin expression but weakened immunofluorescence staining of the cytoskeleton. These propofol-induced changes may be due to the depolymerization of F-actin, which is the main component of the cytoskeleton. Similarly, Garib et al. observed that actin reorganization occurred within 20 min of propofol treatment in MDA-MB-468 cells [26]. A study by Mammoto demonstrated that propofol ( $30 \mu \mathrm{M}, 60 \mathrm{~min})$ inhibits the formation of actin stress fibers [14]. We further examined changes in cell surface ultrastructure in response to higher concentrations of propofol, and stimulation with $40 \mu \mathrm{M}$ propofol for $3 \mathrm{~h}$ induced even more significant changes in the F-actin cytoskeleton.

We also analyzed the important role of propofol in regulating the migration capability of HeLa cells due to the positive role of the cytoskeleton in tumor cell metastasis dynamics using wound healing and transwell membrane assays. Treatment with propofol for $12 \mathrm{~h}$ decreased cell migration in a concentration-dependent manner compared with the control group. Notably, treatment with $30 \mu \mathrm{M}$ propofol almost completely inhibited the migration capacity of HeLa cells. Mammoto and colleagues demonstrated that propofol (6 to $30 \mu \mathrm{M}$ ) effectively inhibits the invasion ability of a variety of tumor cell lines [14], which is consistent with our results. We also detected the effects of propofol on cell proliferation, growth and apoptosis, and the results show that different concentrations of propofol can significantly inhibit the proliferation of cervical cancer cells while promoting apoptosis (Fig. 1 and 2). This finding is consistent with the effects of propofol on tumor suppression that have been detailed in the literature.

The cell membrane plays a key role in the physiological processes of cells, and normal cell function is directly influenced by changes in cell membrane structure [39]. Lamellipodia formation at the edges of cells is a prerequisite for the induction of cell migration [40]. AFM scanning analyses demonstrated that cell membrane ultrastructure in HeLa cells was substantially altered following propofol treatment. These cells exhibited an evident decrease in membrane roughness, and their lamellipodia were obviously retracted or disappeared. These AFM results provide further evidence of the effects of propofol on the migration behavior of HeLa cells.

Cytoskeletal alterations change the overall morphological properties of a cell. Propofol significantly altered the levels of the main cytoskeletal component, F-actin, and this effect impacted the morphological properties of the cell membrane. The mechanisms underlying these alterations might be related to proteins that participate in remodeling of the actin cytoskeleton. However, Garib et al. reported that HeLa cells treated with $30 \mu \mathrm{M}$ propofol for $60 \mathrm{~min}$ exhibited no redistribution of the actin cytoskeleton. Using a prolonged reaction time $(3 \mathrm{~h})$ and an increased drug concentration $(40 \mu \mathrm{M})$, we observed obvious cytoskeletal changes in immunofluorescence images. AFM scanning analyses demonstrated that cell membrane ultrastructure was substantially changed following treatment with propofol, with a clear increase in membrane roughness.

These observations are consistent with the hypothesis that reduced organization and decreased intensity of F-actin (the most important component of the cytoskeleton) are related to the alterations in cell membrane ultrastructure that have been observed in propofol-treated HeLa cells. Therefore, the influence of propofol on the HeLa cell cytoskeleton is directly reflected by cell membrane ultrastructure, as demonstrated by AFM.

SEM, TEM, and optical microscopy are important methods for studying cellular morphology and physiological capacity, and these techniques provide a great deal of information regarding the structural characteristics of cells. However, AFM provides images showing the physiological conditions of the cell membrane at nanoscale resolution. The cytoskeleton primarily defines cell morphology and size. Therefore, AFM constitutes a good method for investigating how propofol treatment alters cytoskeletal characteristics and membrane surface ultrastructure. Further research consisting of clinical trials and in vivo models is imminently needed to evaluate the optimal concentration of propofol to administer to cancer patients in clinical settings. 


\section{Cellular Physiology Cell Physiol Biochem 2016;40:172-182 \begin{tabular}{l|l|l} 
and Biochemistry & $\begin{array}{l}\text { DOI: 10.1159/000452535 } \\
\text { Published online: November 18, } 2016\end{array}$ & $\begin{array}{l}\text { (c) } 2016 \text { The Author(s). Published by S. Karger AG, Basel } \\
\text { www.karger.com/cpb }\end{array}$
\end{tabular} \\ Zhang et al.: Effects of Propofol on Membrane Characteristics}

\section{Conclusion}

The influence of propofol on the HeLa cell cytoskeleton can be directly reflected by observing cellular morphology using AFM. Moreover, AFM constitutes a good method for investigating the changes in cytoskeletal ultrastructure that are induced by treatment with propofol.

\section{Acknowledgments}

This work was supported by the National Natural Science Foundation of China (No.51175124), the Foundation of Heilongjiang Health Committee (No.2012-529) and the Foundation of Heilongjiang Educational Committee (no. 12531310).

\section{Disclosure Statement}

All authors declare to have no conflicts of interest associated with this manuscript.

\section{References}

1 Laurent M, Paillaud E, Tournigand C, Caillet P, Le Thuaut A, Lagrange JL, Beauchet O, Vincent H, CarvahloVerlinde M, Culine S, Bastuji-Garin S, Canouï-Poitrine F; ELCAPA Study Group: Assessment of solid cancer treatment feasibility in older patients: a prospective cohort study. Oncologist 2014;19:275-282.

2 Arya M, Bott SR, Shergill IS, Ahmed HU, Williamson M, Patel HR: The metastatic cascade in prostate cancer. Surg Oncol 2006;15:117-128.

3 Defamie N, Chepied A, Mesnil M: Connexins, gap junctions and tissue invasion. FEBS Lett 2014;588:13311338.

4 Spano D, Heck C, De Antonellis P, Christofori G, Zollo M: Molecular networks that regulate cancer metastasis. Semin Cancer Biol 2012;22:234-249.

5 Mammoto T, Mukai M, Mammoto A, Yamanaka Y, Hayashi Y, Mashimo T, Kishi Y, Nakamura H: Intravenous anesthetic, propofol inhibits invasion of cancer cells. Cancer Lett 2002;184:165-170.

6 Zhang L, Wang N, Zhou S, Ye W, Jing G, Zhang M: Propofol induces proliferation and invasion of gallbladder cancer cells through activation of Nrf2. J Exp Clin Cancer Res 2012;31:66.

$7 \quad$ Ye Z, Jingzhong L, Yangbo L, Lei C, Jiandong Y: Propofol inhibits proliferation and invasion of osteosarcoma cells by regulation of microRNA-143 expression. Oncol Res 2013;21:201-207.

8 Zhang J, Zhang D, Wu GQ, Feng ZY, Zhu SM: Propofol inhibits the adhesion of hepatocellular carcinoma cells by upregulating microRNA-199a and downregulating MMP-9 expression. Hepatobiliary Pancreat Dis Int 2013;12:305-309.

9 Garib V, Niggemann B, Zänker KS, Brandt L, Kubens BS: Influence of non-volatile anesthetics on the migration behavior of the human breast cancer cell line MDA-MB-468. Acta Anaesthesiol Scand 2002;46:836-844.

10 Deegan CA, Murray D, Doran P, Ecimovic P, Moriarty DC, Buggy DJ: Effect of anaesthetic technique on oestrogen receptor-negative breast cancer cell function in vitro. Br J Anaesth 2009;103:685-690.

11 Cakmakkaya OS, Kolodzie K, Apfel CC, Pace NL: Anaesthetic techniques for risk of malignant tumour recurrence. Cochrane Database Syst Rev 2014;11:CD008877.

12 Fodale V, D'Arrigo MG, Triolo S, Mondello S, La Torre D: Anesthetic techniques and cancer recurrence after surgery. ScientificWorldJournal 2014;2014:328513.

13 Cata JP, Hernandez M, Lewis VO, Kurz A: Can regional anesthesia and analgesia prolong cancer survival after orthopaedic oncologic surgery? Clin Orthop Relat Res 2014;472:1434-1441.

14 Buckley A, McQuaid S, Johnson P, Buggy DJ: Effect of anaesthetic technique on the natural killer cell antitumour activity of serum from women undergoing breast cancer surgery: a pilot study. Br J Anaesth 2014;113:i56-i62. 


\section{Cellular Physiology Cell Physiol Biochem 2016;40:172-182 \begin{tabular}{l|l|l} 
and Biochemistry $\begin{array}{l}\text { DOI: 10.1159/000452535 } \\
\text { Published online: November 18, } 2016\end{array}$ & $\begin{array}{l}\text { (c) } 2016 \text { The Author(s). Published by S. Karger AG, Basel } \\
\text { www.karger.com/cpb }\end{array}$
\end{tabular} \\ Zhang et al.: Effects of Propofol on Membrane Characteristics}

15 Tzoneva D, Cherkezov J, Georgiev S, Masljankov S, Todorov G: Long-term consequences of anesthetic technique after cancer surgery. Khirurgiia 2014;2:69-74.

16 Anderson SL, Duke-Novakovski T, Singh B: The immune response to anesthesia: part 2 sedatives, opioids, and injectable anesthetic agents. Vet Anaesth Analg 2014;41:553-566.

17 Meserve JR, Kaye AD, Prabhakar A, Urman RD: The role of analgesics in cancer propagation. Best Pract Res Clin Anaesthesiol 2014;28:139-151.

18 Mathieu PS, Loboa EG: Cytoskeletal and focal adhesion influences on mesenchymal stem cell shape, mechanical properties, and differentiation down osteogenic, adipogenic, and chondrogenic pathways. Tissue Eng B Rev 2012;18:436-444.

19 Yu H, Lim KP, Xiong S, Tan LP, Shim W: Functional morphometric analysis in cellular behaviors: shape and size matter. Adv Healthc Mater 2013;2:1188-1197.

20 Jiang P, Enomoto A, Takahashi M: Cell biology of the movement of breast cancer cells: intracellular signalling and the actin cytoskeleton. Cancer Lett 2009;284:122-130.

21 Heidemann SR, Wirtz D: Towards a regional approach to cell mechanics. Trends Cell Biol 2004;14:160-166.

22 Kedrin D, van Rheenen J, Hernandez L, Condeelis J, Segall JE: Cell motility and cytoskeletal regulation in invasion and metastasis. J Mammary Gland Biol Neoplasia 2007;12:143-152.

23 Rathinam R, Berrier A, Alahari SK: Role of Rho GTPases and their regulators in cancer progression. Front Biosci (Landmark Ed) 2011;16:2561-2571.

24 Niu H, Wu B, Jiang H, Li H, Zhang Y, Peng Y, He P: Mechanisms of RhoGDI2 mediated lung cancer epithelialmesenchymal transition suppression. Cell Physiol Biochem 2014;34:2007-2016.

25 Chen Y, Chou WC, Ding YM, Wu YC: Caffeine inhibits migration in glioma cells through the ROCK-FAK pathway. Cell Physiol Biochem 2014;33:1888-1898.

26 Garib V, Lang K, Niggemann B, Zänker KS, Brandt L, Dittmar T: Propofol-induced calcium signalling and actin reorganization within breast carcinoma cells. Eur J Anaesthesiol 2005;22:609-615.

27 Seely AJ, Pascual JL, Christou NV: Science review: cell membrane expression (connectivity) regulates neutrophil delivery, function and clearance. Crit Care 2003;7:291-307.

28 Azuma Y, Sato H, Higai K, Matsumoto K: Enhanced expression of membrane-associated sialidase Neu3 decreases GD3 and increases GM3 on the surface of Jurkat cells during etoposide-induced apoptosis. Biol Pharm Bull 2007;30:1680-1684.

29 Kreplak L, Richter K, Aebi U, Herrmann H: Electron microscopy of intermediate filaments: teaming up with atomic force and confocal laser scanning microscopy. Methods Cell Biol 2008;88:273-297.

30 Allen TD, Rutherford SA, Murray S, Drummond SP, Goldberg MW, Kiseleva E: Scanning electron microscopy of nuclear structure. Methods Cell Biol 2008;88:389-409.

31 Crawford BJ, Burke RD: TEM and SEM methods. Methods Cell Biol 2004;74:411-441.

32 Sjollema KA, Schnell U, Kuipers J, Kalicharan R, Giepmans BN: Correlated light microscopy and electron microscopy. Methods Cell Biol 2012;111:157-173.

33 Picas L, Milhiet PE, Hernández-Borrell J: Atomic force microscopy: a versatile tool to probe the physical and chemical properties of supported membranes at the nanoscale. Chem Phys Lipids 2012;165:845-860.

34 Vahabi S, Nazemi Salman B, Javanmard A: Atomic force microscopy application in biological research: a review study. Iran J Med Sci 2013;38:76-83.

35 Allison DP, Mortensen NP, Sullivan CJ, Doktycz MJ: Atomic force microscopy of biological samples. Wiley Interdiscip Rev Nanomed Nanobiotechnol 2010;2:618-634.

36 Müller DJ, Dufrêne YF: Atomic force microscopy: a nanoscopic window on the cell surface. Trends Cell Biol 2011;21:461-469.

37 Dorobantu LS, Goss GG, Burrell RE: Atomic force microscopy: a nanoscopic view of microbial cell surfaces. Micron 2012;43:1312-1322.

38 Huang CP, Cheng CM, Su HL, Lin YW: Syndecan-4 promotes epithelial tumor cells spreading and regulates the turnover of PKC $\alpha$ activity under mechanical stimulation on the elastomeric substrates. Cell Physiol Biochem 2015;36:1291-1304.

39 Gu S, Honisch S, Kounenidakis M, Alkahtani S, Alarifi S, Alevizopoulos K, Lang F: Membrane androgen receptor down-regulates c-src-activity and beta-catenin transcription and triggers GSK-3betaphosphorylation in colon tumor cells. Cell Physiol Biochem 2014;34:1402-1412.

40 Schachtner H, Calaminus SD, Thomas SG, Machesky LM: Podosomes in adhesion, migration, mechanosensing and matrix remodeling. Cytoskeleton (Hoboken) 2013;70:572-589. 